\title{
WAKTU PANEN YANG TEPAT MENENTUKAN KANDUNGAN GULA \\ BIJI JAGUNG MANIS ( Zea mays saccharata )
}

\author{
SURTINAH \\ Staf pengajar Fakultas Pertanian Universitas Lancang Kuning \\ Jurusan Budidaya Pertanian \\ Jl. D.I Panjaitan Km.8 Rumbai Telp (0761) 52439
}

\begin{abstract}
ABSRACT
The research was done experimentaly which used completely the randomized design, and the design of treatment is the age of harvest that consist of 6 times of harvest, there are the age 55 days, the age 60 days, 65 days, 70 days, 75 days, and the age 80 days, of harvest. The parametre that observed are the amount of leafs, the length of cob, the weight of cob leavy, the weight cob without leaf, the seed sugar content, and the content of seed moisturizer. The result of this research shown that the different of age harvest really influence for all the parametre determine. And the age harvest that gives the highest sweet corn seed sugar content is 70 days after planting.
\end{abstract}

Key words : Zea mays saccharata, the age harvest, seed sugar content. 


\section{PENDAHULUAN}

Produksi jagung manis Nasional dari tahun ke tahun mengalami penurunan. Diakhir tahun 2000 yaitu 9.344.926 ton sedang diakhir tahun 2002 yaitu 9.277.258 ton ( Marzuki, 2002). Demikian juga untuk daerah Riau mengalami penurunan produksi dimana akhir tahun 2002 produksinya 38.588 ton, sedangkan pada tahun 2001 produksi mencapai 39.467 ton. Berdasarkan survey yang telah dilakukan pada beberapa pedagang dan penjual di pasar, dan tempat keramaian lainnya diperoleh informasi bahwa kebutuhan jagung manis setiap harinya mencapai 8000 10.000 tongkol pada hari - hari biasa, sedangkan pada hari libur atau pada malam hari, dan pada hari minggu kebutuhan dapat mencapai 12.000 tongkol ( Badan Pusat Statistik, 2003 ).

Jagung manis sesuai dengan namanya memiliki kadar gula yang cukup tinggi yaitu 5-6\% ( Palungkun, 1995 ), sehingga rasanya lebih manis dari jagung biasa, namun ada juga varietas lokal yang memiliki kadar gula $9-11 \%$, sedangkan vaitas Hybrid Super Sweet Corn memiliki kadar gula 16 - $18 \%$ ( Siswono, 2004 ).
Tanaman jagung manis biasanya dikonsumsi pada waktu masih segar dan muda, karena apabila jagung waktu pemanenannya terlalu tua, maka jagung tersebut rasanya tidak manis lagi dan kualitas akan menurun. Untuk memperoleh hasil biji yang lunak dan manis jagung harus dipanen pada fase masak susu sebelum masak tua karena kandungan gula masih tinggi. Jagung manis yang dipanen terlalu tua akan memiliki kandungan gula rendah dan biji akan keriput. Apabila pemanenan terlalu awal juga dapat menyebabkan kualitas menjadi rendah.

Jagung manis berumur lebih genjah, dan tongkol siap dipanen ketika tanaman berumur 60 - 70 hari setelah tanam ( Tim Trubus, 2002 ). Sementara itu Iskandar ( 2006 ) melaporkan bahwa jagung manis dapat dipanen pada umur 60 - 75 setelah tanam. Surtinah ( 2007 ) melaporkan bahwa jagung manis yang dipanen pada umur lebih dari 75 hari menghasilkan biji dengan tekstur yang lebih keras dan biji berkerut sehingga menurunkan kualitas produksi.

Jagung manis banyak mengandung gula bebas dan pati, yang merupakan polimer dari gula tersebut, kandungan gula pada

Jurnal Ilmiah Pertanian Vol. 4 No. 2 Februari 2008 
jagung manis bukan merupakan glukosa atau sukrosa, namun dalam bentu fruktosa, sejenis polimer gula yang dikenal dengan gula buah. Fruktosa merupakan gula kompleks yang tidak langsung dicerna oleh alat pencernaan manusia, tetapi harus diolah terlebih dahulu menjadi gula sederhana. Sebelum fruktosa tercerna, biasanya sudah terbuang bersama urin, sehingga tidak sempat terserap ( Wahyudi, 2005 ).

Kandungan gula pada jagung manis akan sangat menentukan kualitasnya. Kualitas hasil diukur dalam bentuk kandungan gula. Semakin tinggi kandungan gula maka kualitasnya semakin baik. Sukrosa dan gula reduksi ( glukosa dan fruktosa ) hasil fotosintesis yang ditransfer ke berbagai organ pengguna yang kemudian sebagian digunakan untuk pemeliharaan integritas organ tersebut, sebagian lagi dikonversi ke bahan struktur tanaman dan sisanya sebagai cadangan makanan ( Harini, 1993 ).

Siswono ( 2004 ) melaporkan bahwa kandungan gula jagung manis 16 - $18 \%$, mendekati kadar gula tebu yaitu $19 \%$, sedangkan jagung manis lokal hanya $9-11 \%$.
Nurhayati ( 2002 ) melaporkan bahwa umur panen 65 hari dan takaran pupuk kandang 3 ton / ha dapat memberikan hasil berat tongkol berkelobot 438,61 g; berat tongkol tanpa kelobot 360,67 g; berat tongkol layak jual 399,34 g; dan kandungan gula 5,4\%. Kualitas jagung manis ditentukan oleh adanya kandungan gula yang dikandung oleh biji jagung manis. Pemanenan yang tepat akan mempengaruhi kualitas jagung manis, karena apabila pemanenan terlambat, menyebabkan jagung manis menjadi keriput, karena terjadi perubahan gula menjadi pati di dalam biji, yang menyebabkan rasanya tidak manis.

Umur panen sangat berpengaruh terhadap persentase bagian yang dapat dimakan ( edible portion ). Mutu jagung manis yang dipanen terlalu awal bijinya lebih kecil, sehingga bagian yang dapat dimakan lebih rendah. Sedang jagung yang dipanen terlambat akan berkurang kemanisannya dan biji jagung mempunyai tekstur yang keras ( Purwanto dan Wahyuni, 1988 ). Tujuan Penelitian adalah untuk mendapatkan umur panen jagung manis yang paling tepat dengan kandungan gula biji yang paling tinggi. 


\section{BAHAN DAN METODE}

Bahan yang digunakan adalah benih jagung manis varietas Sweet Boy, pupuk NPK, pupuk Urea, pupuk kandang ayam, Decis 2.5 EC, dan Dithane M-45. Sedangkan alat yang digunakan adalah timbangan Ohaus, Hand refraktometer, Selang, meteran, alat tulis, hand sprayer.

Penelitian ini merupakan penelitian eksperimen, menggunakan Rancangan lingkungan Acak Lengkap dengan 3 kali ulangan. Rancangan Perlakuan yang akan diamati adalah umur panen ( $U$ ) yang terdiri dari 6 ( enam ) taraf, yaitu:

$\mathrm{U}_{1}=$ umur panen 55 hari; $\mathrm{U}_{2}=$ umur panen 60 hari; $\mathrm{U}_{3}=$ umur panen 65 hari;

$\mathrm{U}_{4}=$ umur panen 70 hari; $\mathrm{U}_{5}=$ umur panen 75 hari; $\mathrm{U}_{6}=$ umur panen 80 hari

Populasi tanaman pada setiap plot adalah 8 ( delapan ) tanaman dan 4 tanaman dijadikan tanaman sampel, jumlah tanaman seluruhnya adalah 144 tanaman. Data yang diperoleh dianalisa dengan menggunakan Sidik Ragam pada peluang 5\% ( Gomez and Gomez, 1995 ).

\section{Pelaksanaan penelitian}

Lahan dibersihkan, selanjutnya dilakukan pengolahan tanah sebanyak dua kali. Pengolahan tanah yang pertama bertujuan untuk membalikkan tanah dan menghancurkan bongkahanbongkahan tanah agar lebih gembur. Pengolahan tanah yang ke dua bertujuan untuk memperbaiki aerasi tanah, sehingga kehidupan mikroorganisme tanah menjadi lebih baik.

pembuatan plot sebanyak 18 plot dengan ukuran 150 x 100 $\mathrm{cm}$, dengan jarak antar plot $75 \mathrm{~cm}$.

Penanaman benih secara tugal dengan kedalaman lebih kurang $3 \mathrm{~cm}$ dengan jarak tanam $20 \times 75 \mathrm{~cm}$. Setiap lubang tanam dimasukkan 4 benih, lalu ditutup dengan sedikit tanah. Setelah tumbuh dibiarkan 1 tanaman tiap lubang tanam untuk diamati.

Jurnal Ilmiah Pertanian Vol. 4 No. 2 Februari 2008 
Pemberian pupuk NPK diberikan 1 kali pada waktu tanam dengan dosis $5 \mathrm{~g} /$ tanaman. Pupuk dibenamkan ke dalam tanah sedalam $5 \mathrm{~cm}$ melingkar dengan jarak $5 \mathrm{~cm}$ dari benih, kemudian ditutup tanah.

Pupuk Urea diberikan dua kali yaitu $5 \mathrm{~g}$ pada umur 21 hari setelah tanam, 5 g pada saat tanaman berumur 35 hari, pupuk dibenamkan dengan jarak $10 \mathrm{~cm}$ dari tanaman dengan kedalaman $7 \mathrm{~cm}$.

Pupuk kandang diberikan bersamaan dengan pengolahan tanah kedua dua minggu sebelum tanam dengan dosis 20 ton/ha ( $3 \mathrm{~kg} / \mathrm{plot}$ ).

Pencegahan serangan hama digunakan Decis 2,5 EC dengan konsentrasi $2 \mathrm{ml} / \mathrm{l}$ air dan untuk pencegahan penyakit digunakan Dithane M-45 dengan konsentrasi $2 \mathrm{~g} / \mathrm{l}$ air, penyemprotan dilakukan pada saat tanaman berumur 4 dan 8 minggu setelah tanam.

Tanaman jagung manis disiram dua kali dalam sehari yaitu pagi dan sore hari dengan volume air yang sama yaitu 1 liter/tanaman, dan pemberian disesuaikan dengan umur tanaman.
Perlakuan sesuai dengan Rancangan perlakuan yang sudah ditentukan yaitu panen pada waktu tanaman berumur 55 hari, 60 hari, 65 hari, 70 hari, 75 hari, dan 80 hari setelah tanam.

Objek pengamatan pada penelitian ini meliputi : jumlah daun, panjang tongkol berkelobot, berat tongkol berkelobot / tanaman, berat tongkol tanpa kelobot, kandungan gula biji saat panen, dan kandungan air biji pada saat panen.

\section{HASIL DAN PEMBAHASAN PENELITIAN}

Hasil Pengamatan terhadap parameter jumlah daun, panjang tongkol berkelobot, berat tongkol berkelobot, berat tongkol tanpa kelobot, kandungan gula biji, kadar air biji ditampilkan pada tabel di bawah ini.

\begin{tabular}{|l|l|l|l|l|l|}
\hline \multirow{2}{*}{$\begin{array}{c}\text { Umur } \\
\text { panen }\end{array}$} & \multicolumn{5}{|c|}{ Jmata - rata hasil pengamatan terhadap parameter } \\
\cline { 2 - 6 } & $\begin{array}{c}\text { Pjg.tgkl. } \\
\text { berkelobot }\end{array}$ & $\begin{array}{c}\text { Berat tgkl. } \\
\text { berkelobot }\end{array}$ & $\begin{array}{c}\text { Brt.tgkl.tanpa } \\
\text { kelobot }\end{array}$ & Kdg. Gula biji \\
\hline 55 hari & 9.22 & $27.67 \mathrm{a}$ & $141.95 \mathrm{a}$ & $57.69 \mathrm{a}$ & $8.44 \mathrm{a}$ \\
\hline 60 hari & 9.78 & $29.44 \mathrm{ab}$ & $229.49 \mathrm{~b}$ & $136.35 \mathrm{~b}$ & $8.94 \mathrm{ab}$ \\
\hline 65 hari & 9.87 & $31.45 \mathrm{~b}$ & $310.15 \mathrm{c}$ & $221.67 \mathrm{c}$ & $10.89 \mathrm{abc}$ \\
\hline 70 hari & 10.45 & $29.56 \mathrm{ab}$ & $384.53 \mathrm{~d}$ & $288.89 \mathrm{~d}$ & $15.78 \mathrm{c}$ \\
\hline 75 hari & 10.44 & $29.56 \mathrm{ab}$ & $395.52 \mathrm{~d}$ & $296.49 \mathrm{~d}$ & $15.00 \mathrm{c}$ \\
\hline 80 hari & 9.78 & $29.56 \mathrm{ab}$ & $401.89 \mathrm{~d}$ & $304.56 \mathrm{~d}$ & $13.22 \mathrm{bc}$ \\
\hline
\end{tabular}

Jurnal Ilmiah Pertanian Vol. 4 No. 2 Februari 2008 
Angka yang diikuti oleh huruf kecil yang sama berbeda tidak nyata berdasarkan uji DMRT taraf $5 \%$.

Tabel di atas memperlihatkan bahwa jumlah daun jagung manis yang dihitung pada umur panen yang berbeda lebih dipengaruhi oleh faktor genetiknya dibandingkan faktor lingkungannya. Pada saat panen pertama sampai panen terakhir jumlah daun jagung manis sudah mencapai batas maksimum sesuai dengan genetiknya, karena pada saat itu tidak terjadi lagi pertambahan jumlah daun, justru yang terjadi adalah proses pertumbuhan generatif yang lebih aktif. Hal ini didukung oleh Efendi ( 2002 ) yang menyatakan bahwa pertumbuhan dan produksi jagung manis dipengaruhi oleh faktor genetik dan lingkungan dimana jagung tersebut tumbuh.

Hasil rata - rata panjang tongkol jagung manis yang dipanen pada waktu yang berbeda memperlihatkan panjang yang berbeda pula, namun pada umur panen 70 hari sampai 80 hari memperlihatkan panjang tongkol yang sama. Sementara itu panjang tongkol terpanjang diperoleh pada umur panen 65 hari setelah tanam. Walaupun panjang tongkol jagung manis yang dipanen pada umur 65 hari lebih panjang $1.89 \mathrm{~cm}$, namun perbedaan panjang ini masih dianggap tidak nyata, sehingga diasumsikan bahwa panjang tongkol jagung manis yang dipanen pada umur 60 hari sampai 80 hari adalah sama. Sesuai dengan diskripsi jagung manis varietas sweet boy bahwa umur panen yang dianjurkan adalah pada umur 65 hari ( Tanindo Subur Prima, 2006 ). Sama dengan penelitian yang dilakukan oleh Nurhayati ( 2002 ) yang melaporkan umur panen yang berbeda menghasilkan panjang tongkol yang berbeda nyata, dan pada penelitian tersebut panjang tongkol terpanjang diperoleh pada umur panen 65 hari yaitu $19.02 \mathrm{~cm}$, jauh dibawah penelitian ini, kenapa hal ini bisa terjadi mungkin disebabkan karena varietas yang berbeda, teknik budidaya yang berbeda, dan perlakuan yang berbeda pula.

Berat tongkol berkelobot semakin meningkat dengan meningkatnya umur panen. Umur panen 70 hari sampai dengan 80 hari menghasilkan berat tongkol yang tinggi dibandingkan dengan umur panen lebih awal. Peningkatan berat tongkol ada kaitannya dengan lamanya waktu panen jagung manis, semakin

Jurnal Ilmiah Pertanian Vol. 4 No. 2 Februari 2008 
lama waktu panen maka semakin banyak waktu yang digunakan oleh tongkol untuk menghimpun bahan kering yang ada di bagian sumber dan dipindahkan ke tongkol. Assimilat yang digunakan untuk pengisian biji diperoleh dari tiga sumber utama yaitu fotosintesis daun saat sekarang, fotosintesis bagian lain yang bukan daun saat sekarang, dan remobilisasi hasil assimilasi yang disimpan dalam organ tanaman yang lain ( Gardner et al, 1991 ).

Budiyati ( 1996 ) melaporkan bahwa hasil jagung manis ditentukan dalam bentuk tongkol kotor yaitu tongkol beserta kelobotnya, sehingga yang menentukan hasil tanaman adalah besarnya fotosintat yang terdapat pada daun dan batang, artinya jika transport fotosintat dari kedua organ tersebut dapat ditingkatkan selama fase pengisian biji maka hasil tanaman yang berupa biji dapat ditingkatkan. Dengan lamanya waktu panen maka peluang untuk menghimpun bahan kering ke dalam biji menjadi lebih lama dan lebih banyak.

Berat tongkol tanpa kelobot / tanaman antara umur panen 55 hari dengan 60 hari terlihat peningkatan bahan kering yang tinggi sekali, dimana peningkatannya sampai mencapai $136.35 \%$.
Diduga pada saat inilah terjadi penimbunan bahan kering dari daerah sumber ke daerah lumbung yang paling efektif, dan selanjutnya peningkatan bahan kering terjadi sebesar $62.57 \%$ antara umur panen 60 hari sampai 65 hari dan terus menurun seiring dengan bertambahnya umur panen, mungkin hal ini disebabkan karena bahan kering sudah menipis persedianaannya di daerah sumber. Berturut-turut peningkatan bahan kering dari umur panen 65 sampai 70 hari yaitu $30.32 \%$, umur panen 70 sampai 75 hari $2.77 \%$, dan umur panen 75 hari sampai 80 hari adalah $2.72 \%$.

Bila dibandingkan dengan penelitian yang dilakukan oleh Nurhayati ( 2002 ), hasil berat tongkol tanpa kelobot dengan umur panen 60 hari yaitu $238.75 \mathrm{~g}$, umur panen 65 hari berat tongkol tanpa kelobot yaitu $271.81 \mathrm{~g}$, sedangkan umur panen 70 hari menghasilkan berat tongkol tanpa kelobot 246.48 g, maka hasil penelitian yang dilaksanakan di kebun Percobaan fakultas pertanian unilak lebih unggul dalam berat tongkol tanpa kelobot / tanaman. 
Pada Tabel 5. di atas menunjukkan bahwa kadar gula biji jagung manis yang dipanen lebih awal memperlihatkan kadar gula yang paling rendah. Sampai umur panen 65 hari kadar gula biji jagung manis belum menunjukkan beda nyata dengan panen yang lebih awal, walaupun sudah terjadi peningkatan kandungan gula biji sampai $29.03 \%$. Namun peningkatan kandungan gula biji yang paling pesat adalah waktu panen 65 hari sampai 70 hari yaitu $44.90 \%$. Dan umur panen 70 hari merupakan umur panen yang paling tepat untuk musim tanam antara bulan Juni sampai Agustus 2007.

Panen jagung manis varitas sweet boy adalah 65 hari, namun pada penelitian ini jagung manis yang dipanen pada umur 65 hari setelah tanam memperlihatkan kadar gula yang rendah yaitu $10.89 \%$. Hal ini disebabkan karena hari - hari sebelum umur panen 65 hari penyinaran matahari intensitasnya hanya 35 $\%$ - $49 \%$. Sedangkan pada waktu umur panen 70 hari intensitas cahaya matahari berkisar antara $68-83 \%$. Cahaya matahari sangat menentukan proses fotosintesis, dan dari proses fotosintesis inilah karbohidrat akan dihasilkan, semakin banyak karbohidrat yang dihasilkan melalui proses fotosintesis maka akan semakin tinggi kandungan gula yang terakumulasi pada biji jagung manis.

Nurhayati ( 2002 ) melaporkan bahwa kandungan gula biji jagung manis yang dipanen pada umur 65 hari hanya $4.01 \%$, sedangkan yang dipanen pada umur 70 hari kandungan gula biji hanya $3.59 \%$.

Kandungan gula biji jagung manis sangat menentukan kualitasnya. Semakin tinggi kandungan gula biji maka kualitasnya semakin baik. Pada umur 70 hari biji jagung manis memasuki stadia masak susu, yang ditandai dengan cairan seperti susu akan keluar bila biji ditekan, dan dalam kondisi ini biji jagung masih lunak. Salunke dan Desai berpendapat ( 1984 ) bahwa umur panen pada fase masak susu ( milk ) ditandai dengan kadar gula yang tinggi sedangkan kadar pati rendah.

Pada umur panen 80 hari kandungan gula biji jagung manis turun sampai $13.46 \%$, hal ini disebabkan karena pada saat ini terjadi perubahan gula menjadi tepung, sehingga mengurangi rasa manis dari biji jagung tersebut. Dan pada umur panen 80

Jurnal Ilmiah Pertanian Vol. 4 No. 2 Februari 2008 
hari serat biji jagung manis lebih kasar dibandingkan dengan umur panen yang lain.

\section{KESIMPULAN}

Umur panen yang berbeda akan mempengaruhi kandungan gula biji jagung manis. Dan umur panen yang paling tepat adalah pada umur 70 hari setelah tanam, karena pada umur panen ini kandungan gula biji jagung manis mencapai $15.78 \%$.

\section{DAFTAR PUSTAKA}

Badan Pusat Statistik, 2003. Survey Lapangan Produksi Jagung Manis. Pekanbaru. Pekanbaru.

Effendi, 2002. Bercocok tanam jagung. CV. Yasaguna. Jakarta. Gomez, K. A. and A. A. Gomez, 1984. Statistic Procedures for Agricultural Research. Internatinal Rice Research Institute, Second edition. Jhon Wiley and Sons. Inc. Los Banos. Philippines.

Harini, N., 1993. Pengaruh Umur Panen dan Suhu Pendinginan terhadap Perubahan Beberapa Sifat Fisika Kimia Jagung Segar Selama Periode Penyimpanan. Tesis. Program Pasca sarjana. UGM. Program KPK Unibraw - Malang.

Iskandar, D., 2006. Pengaruh Dosis Pupuk N, P, dan K terhadap Pertumbuhan dan Produksi Tanaman Jagung Manis di
Lahan Kering. Jurnal Saint dan Teknologi. IPTEK net. Hal $1-2$.

Marzuki, R., 2002. Bertanam Jagung Manis. Penebar swadaya. Jakarta.

Nurhayati, S., 2002. Pengaruh Takaran Pupuk Kandang dan Umur Panen Terhadap Hasil dan Kandungan Gula Jagung Manis. Laporan Penelitian. Lembaga penelitian Universitas Terbuka. 34 hal.

Purwanto, I.M., dan Wahyuni, S. 1988. Teknik Budidaya Jagung Manis. Bina Bangsa. Bogor.

Salunke, D. K. and B. B. desai, 1984. Sweet Corn. In Possharvest Bio Technology of vegetables. P. $107-116$.

Siswono, 2004. Jagung Manis Rendah Lemak dan Kolesterol. Gizi net.

Surtinah., 2007. Menguji 5 macam pupuk daun dengan mengukur kadar gula total biji jagung manis ( Zea mays saccharata). Jurnal Ilmiah Pertanian Vol. 3. No. $2 ; 1-6$.

Tanindo subur prima, 2006. Benih jagung manis hibrida sweet boy. Chia Thai Seed. Surabaya-Jawa Timur.

Tim Trubus, 2002. Sweet corn Baby corn. Penebar swadaya.. Jakarta. 